\title{
Prediction of soil shear strength in agricultural and natural environments of the Brazilian Cerrado
}

\author{
Reginaldo Barboza da Silva( ${ }^{(1)}$, Moacir de Souza Dias Junior(2), Piero lori(1), Francisca Alcivânia de Melo Silva(1), \\ Sergio Mauro Folle ${ }^{(3)}$, Claudio Alberto Bento Franz ${ }^{(3)}$ and Zigomar Menezes de Souza ${ }^{(4)}$
}

\begin{abstract}
(1)Universidade Estadual Paulista, Campus Experimental de Registro, Avenida Nelson Brihi Badur, no 430, Vila Tupy, CEP 11900-000 Registro, SP, Brazil. E-mail: rbsilva@registro.unesp.br, pieroiori@registro.unesp.br, alcivania@registro.unesp.br (2)Universidade Federal de Lavras, Departamento de Ciência do Solo, Caixa Postal 3037, CEP 37200-000 Lavras, MG, Brazil. E-mail: msouzadj@dcs.ufla.br (3)Embrapa Cerrados, Rodovia BR-020, Km 18, Caixa Postal 08223, CEP 73310-970 Planaltina, DF, Brazil. E-mail: sergio.folle@embrapa.br, claudio.franz@embrapa.br (4)Universidade Estadual de Campinas, Departamento de Água e Solo, Avenida Cândido Rondon, no 501, Cidade Universitária Zeferino Vaz, Barão Geraldo, CEP 13083-875 Campinas, SP, Brazil. E-mail: zigomarms@feagri.unicamp.br
\end{abstract}

Abstract - The objective of this work was to develop uni- and multivariate models to predict maximum soil shear strength $\left(\tau_{\max }\right)$ under different normal stresses $\left(\sigma_{\mathrm{n}}\right)$, water contents $(\mathrm{U})$, and soil managements. The study was carried out in a Rhodic Haplustox under Cerrado (control area) and under no-tillage and conventional tillage systems. Undisturbed soil samples were taken in the $0.00-0.05 \mathrm{~m}$ layer and subjected to increasing $\mathrm{U}$ and $\sigma_{\mathrm{n}}$, in shear strength tests. The uni- and multivariate models - respectively $\tau_{\max }=10^{(\mathrm{a}+\mathrm{bU})}$ and $\tau_{\max }=10^{\left(\mathrm{a}+\mathrm{bU}+\mathrm{c} \sigma_{\mathrm{n}}\right)}-$ were significant in all three soil management systems evaluated and they satisfactorily explain the relationship between $\mathrm{U}, \sigma_{\mathrm{n}}$, and $\tau_{\max }$. The soil under Cerrado has the highest shear strength $(\tau)$ estimated with the univariate model, regardless of the soil water content, whereas the soil under conventional tillage shows the highest values with the multivariate model, which were associated to the lowest water contents at the soil consistency limits in this management system.

Index terms: cohesion limits, machine-ground interaction, mechanical resistance, precompression stress, soil compaction, soil physical quality.

\section{Predição da tensão de cisalhamento do solo em ambientes agrícola e natural do Cerrado brasileiro}

\begin{abstract}
Resumo - O objetivo deste trabalho foi desenvolver modelos uni e multivariados para estimar a tensão de cisalhamento máxima $\left(\tau_{\text {maxx }}\right)$, sob diferentes tensões normais $\left(\sigma_{\mathrm{n}}\right)$, conteúdos de água $(U)$ e manejos do solo. O estudo foi realizado em Latossolo Vermelho distrófico sob Cerrado (área controle) e sob os sistemas de plantio direto e convencional. Amostras indeformadas foram retiradas na camada de $0,00-0,05 \mathrm{~m}$ e submetidas a $\mathrm{U}$ e $\sigma_{\mathrm{n}}$ crescentes, durante ensaios de resistência ao cisalhamento. Os modelos uni e multivariados - respectivamente $\tau_{\text {máx }}=10^{(a+b U)}$ e $\tau_{\text {máx }}=10^{\left(a+b U+c \sigma_{n}\right)}$ - foram significativos nos três sistemas de manejo do solo avaliados e explicam satisfatoriamente a relação entre $\mathrm{U}, \sigma_{\mathrm{n}} \mathrm{e} \tau_{\text {máx }}$. O solo sob Cerrado apresenta a maior tensão de cisalhamento $(\tau)$ estimada com uso do modelo univariado, independentemente do conteúdo de água do solo, enquanto o solo sob manejo convencional apresenta os maiores valores com o modelo multivariado, os quais estão associados a menores conteúdos de água nos limites de consistência do solo, nesse sistema de manejo.
\end{abstract}

Termos para indexação: limites de coesão, interação solo-máquina, resistência mecânica, pressão de pré-consolidação, compactação do solo, qualidade física do solo.

\section{Introduction}

Comparative studies of natural and agricultural environments have shown physical and mechanical degradation of soil properties under intense cultivation (Silva et al., 2009; Iori et al., 2012a). Native Cerrado soils have adequate physical properties, which change with the onset of farming practices, especially in intensive or in inappropriate cropping systems.
According to Araujo et al. (2004), quantifying the impact of soil management on its physical quality is fundamental for developing sustainable agricultural systems.

Several tools have been developed for the assessment of soil physical quality. Among these, stand out the evaluation of precompression stress (Silva et al., 2009; Pais et al., 2011; Iori et al., 2012b) and of the shear resistance of soil (Silva et al., 2004; Carvalho et al., 
2010). These tools, besides helping to identify the load-bearing capacity of the soil, can provide proxies for soil compaction degree (Silva et al., 2004; Marasca et al., 2011). Compacted soils have higher values of precompression stress (Pires et al., 2012) and greater shear strength (Bachmann et al., 2006) due to the close proximity between particles, which lessen the voids and increase soil density.

Studies involving soil precompression stress are ubiquitous in the Brazilian and international literature (Ajayi et al., 2010; Severiano et al., 2010; Silva et al., 2010; Araujo-Junior et al., 2011; Pires et al., 2012; Iori et al., 2013); however, the ones on soil shear strength are much more rare, even though it is considered one of the most important dynamic properties for evaluating the machine-ground interaction. This lack of interest can be attributed to the shortage of studies relating shear strength to other soil properties in agricultural soils, particularly under different management systems.

Seeking to partially meet this demand, Silva et al. (2004) assessed the shear strength of a Latossolo Vermelho (Rhodic Hapludox) under different managements and observed higher values in the control area (native forest), followed by the soils under conventional and no-tillage systems. The authors reported that higher levels of organic matter, associated with the soil aggregation model, the level of root entanglement in the soil, and with the presence of physical and chemical bonds between particles in native environments, resulted in higher soil aggregation and, therefore, in higher mechanical resistance. However, Carvalho et al. (2010) found that irrigated pasture and natural bush have similar shear strength, higher than that of nonirrigated pasture. Moreover, the authors stated that the shear strength of soil samples with lower water content $(-33 \mathrm{kPa})$ does not differ between managements. Therefore, studies involving soil mechanical resistance, especially when focusing on the resistance to shearing under dynamic conditions in different management systems, must necessarily consider soil consistency, in order to tackle soil structural degradation.

Most studies evaluate soil shear strength based solely on normal stress (Barbosa et al., 2004) or using the Coulomb equation (Silva et al., 2009; Hossain \& Yin, 2010). The Coulomb equation (univariate) only estimates the parameters' apparent cohesion and angle of internal friction, but it does not relate these parameters or shear stress to soil water contents and to the levels of normal stress in a single equation. Therefore, equations that combine soil water content and levels of normal stress for predicting shear strength can give an important contribution to the analysis of the dynamic mechanical behavior of soils.

The objective of this work was to develop uni- and multivariate models to predict maximum soil shear strength $\left(\tau_{\max }\right)$ under different normal stresses $\left(\sigma_{\mathrm{n}}\right)$, water contents $(\mathrm{U})$, and soil managements.

\section{Materials and Methods}

The research was carried out at Embrapa Cerrados, Planaltina, DF, Brazil $\left(15^{\circ} 36^{\prime} \mathrm{S}, 47^{\circ} 42^{\prime} \mathrm{W}\right.$, at $950 \mathrm{~m}$ altitude). The climate has an average annual temperature around $22^{\circ} \mathrm{C}$ and two clearly distinct seasons: a dry one, from April to September; and a rainy one, from October to March.

The soil in the studied area was a Latossolo Vermelho distrófico (Rhodic Haplustox), according to the Brazilian soil classification system (Santos et al., 2006), with a moderate A horizon, a semideciduous Cerrado vegetation, and a flat terrain. The soil hydrophysical attributes (Donagema et al., 2011) are shown in Table 1 . The precompression stress $\left(\sigma_{\mathrm{p}}\right)$ was obtained as described by Silva et al. (2004).

Three areas with different use and management systems were surveyed: soil under Cerrado, i.e., native vegetation without human intervention; no-tillage system, with four years of use, cultivated with soybean, corn, sorghum, and millet; and conventional tillage system, cultivated for 15 years with soybean. Undisturbed soil samples were taken at the 0.00 $0.05 \mathrm{~m}$ layer with $0.0595 \mathrm{~m}$ width and $0.0225 \mathrm{~m}$ depth, which are dimensions suited for direct semiautomated shear press - done with a Digital Direct/Residual Shear Apparatus machine, model 26-2114/02 (ELE International, Leighton Buzzard, Bedfordshire, UK).

The horizontal velocity of displacement in the shear press was $4.2 \times 10^{-5} \mathrm{~m} \mathrm{~s}^{-1}$, with a time span between readings of $30 \mathrm{~s}$. The dynametric ring was adjusted for the five loads of normal stress employed in the study, and the constant used for the correction of the horizontal force applied to the soil specimens was estimated in laboratory, according to the equation: $\mathrm{F}=0.0447+14.24 \mathrm{~L}$, in which $\mathrm{F}$ is the horizontal force $\left(\mathrm{kg} \mathrm{cm}^{-2}\right)$ and $\mathrm{L}$ is the displacement $(\mathrm{mm})$. The 
direct shear test consisted of sliding half of the soil specimen over the other half, determining the normal stress $\left(\sigma_{\mathrm{n}}\right)$ applied to the sliding surface and the value of shear stress $(\tau)$ required to cause the continuous deformation of the soil, until the failure of the specimen (Lambe, 1951). The rapid assay was used, which is characterized by the simultaneous application of initial tension: normal stress and constant shear stress, the latter being gradually increased until the failure of the specimen. In the test, the specimen was placed in a box containing shear porous plates, so that the lower half of the specimen was within the shear box and the upper half, within the ring. The normal stress was applied simultaneously with a horizontal force applied to the shear box. The latter force caused a constant speed displacement in half of the specimen, and the resistance offered by the other half was recorded by the micrometer dial of the ring dynamometer.

Cohesion intercept, internal friction angle, and shear stress were determined under the following conditions: A, five levels of $\sigma_{\mathrm{n}}-97,194,388,776$, and $1,551 \mathrm{kPa}-$, based on the standards of the American Society of Agricultural Engineers (ASAE), which suggests at least four loads; and $\mathrm{B}$, four levels of soil water contents $-0.05,0.16,0.27$, and $0.38 \mathrm{~kg} \mathrm{~kg}^{-1}-$, chosen according to the limits of consistency observed in each studied area (Table 1).

The analytical procedures used to obtain the rates of stress-strain measurements consisted of the following: A, horizontal deformation $\left(l_{h i}\right)$ of the soil specimen, in

Table 1. Characterization of hydrophysical and mechanical attributes of a Latossolo Vermelho distrófico (Rhodic Haplustox) under Cerrado and no-tillage and conventional tillage systems.

\begin{tabular}{lccc}
\hline Soil attribute & Cerrado & $\begin{array}{c}\text { No- } \\
\text { tillage }\end{array}$ & $\begin{array}{c}\text { Conventional } \\
\text { tillage }\end{array}$ \\
\hline Soil density $\left(\mathrm{g} \mathrm{cm}^{-3}\right)$ & 0.96 & 1.12 & 1.21 \\
Total porosity $\left(\mathrm{m} \mathrm{m}^{3} \mathrm{~m}^{-3}\right)$ & 0.61 & 0.56 & 0.54 \\
Clay content $\left(\mathrm{g} \mathrm{kg}^{-1}\right)$ & 533.00 & 420.00 & 460.00 \\
Organic matter $\left(\mathrm{dag} \mathrm{kg}^{-1}\right)$ & 8.20 & 4.43 & 2.93 \\
Saturated hydraulic conductivity $\left(\mathrm{cm} \mathrm{h}^{-1}\right)$ & 182.90 & 46.60 & 41.30 \\
Shrinkage limit, SL $\left(\mathrm{kg} \mathrm{kg}^{-1}\right)$ & 0.32 & 0.24 & 0.24 \\
Plastic limit, PL $\left(\mathrm{kg} \mathrm{kg}^{-1}\right)$ & 0.43 & 0.28 & 0.33 \\
Liquid limit, $\mathrm{LL}\left(\mathrm{kg} \mathrm{kg}^{-1}\right)$ & 0.52 & 0.35 & 0.40 \\
Precompression stress in SL $(\mathrm{kPa})$ & 214.66 & 232.63 & 215.88 \\
Precompression stress in PL $(\mathrm{kPa})$ & 151.72 & 190.35 & 151.81 \\
Precompression stress in LL $(\mathrm{kPa})$ & 114.22 & 135.47 & 117.72 \\
\hline
\end{tabular}

which every moment was recorded by the horizontal extensometer; B, specific shear deformation ( $\varepsilon i$ ) of the soil specimen, calculated by the $\mathrm{l}_{\mathrm{hi}} / \mathrm{D}$ formula, in which $\mathrm{D}$ is the diagonal length of the specimen, which has a square format - due to the occurrence of volumetric strain during the test, these diagonals are corrected for each $1_{\text {hi }}$, according to the expression $\mathrm{D}=\left[\mathrm{a}^{2}+\left(1-\mathrm{l}_{\mathrm{hi}}\right)^{2}\right]^{0.5}$; $\mathrm{C}$, horizontal force $(\mathrm{Fi})$, calculated with the expression $\mathrm{F}_{\mathrm{i}}=\mathrm{K} 1_{\text {mi }}$, in which $\mathrm{K}$ is the constant of the ring dynamometer used in the test and $1_{\mathrm{mi}}$ is the reading from the ring dynamometer (spring); $\mathrm{D}$, variation in vertical volume $(\Delta v i)$ of the specimen in each instant, calculated by the expression $\Delta \mathrm{v}_{\mathrm{i}}=\mathrm{lv}_{\mathrm{i}}$, in which $\mathrm{lv}_{\mathrm{i}}$ is the reading of the vertical deformation of the specimen; and $E$, determination of the shear force values $(\tau)$, using the relationship $\tau=F_{i} / A_{i}$, in which $F_{i}$ is obtained from the function $\mathrm{F}_{\mathrm{i}}=\mathrm{f}\left(\mathrm{E}_{\mathrm{i}}\right)$ - calculated with a spreadsheet and developed specifically for this study, for each level of $\sigma_{\mathrm{n}}$ and water content, in which Fi is the shear strength and $\mathrm{Ei}$ is the deformation in a certain time and $A_{i}$ is the area of the specimen at each moment. In the present study, the area values were corrected for each Fi, during each test, and $\sigma_{\mathrm{n}}$ were obtained by the $\sigma_{\mathrm{n}}=\mathrm{N} / \mathrm{A}$ ratio, in which $\mathrm{N}$ is the normal load applied during the entire test and $\mathrm{A}$ is the area of the specimen.

After performing the shear tests and processing the data for each level of $\sigma_{\mathrm{n}}$ and soil water content, the average shear stress was obtained. The Mohr-Coulomb theory allowed for the estimation of the intercept (c) and the internal friction angle $(\phi)$ between specimens in the shear tests, according to the equation $\tau=\mathrm{c}+\sigma_{\mathrm{n}} \operatorname{tg} \phi$, in which: $\tau$ is the shear stress; $\mathrm{c}$ is the total cohesion intercept; $\sigma_{\mathrm{n}}$ is the normal stress; and $\operatorname{tg} \phi$ is the slope. Following this theory, the values of maximum shear stress $\left(\tau_{\max }\right.$, in $\left.\mathrm{kPa}\right)$ were extracted for each level of normal stress and adjusted according to the soil water content (U): $\tau_{\max }=10^{\mathrm{a}+\mathrm{bU}}$, in which $\mathrm{a}$ and $\mathrm{b}$ are tuning parameters. Therefore, these models described soil maximum shear resistance based on soil water content.

The models, applied for each studied area, were compared following the homogeneity test procedure, proposed by Snedecor \& Cochran (1989). This procedure compares two linear models, and, therefore, the exponential model $\left(\tau_{\max }\right)$ was linearized. The linear (a) and angular (b) coefficients (tuning parameters), along with the homogeneity data, were compared using the F test. When two models exhibited homogeneity of data and the coefficients did not differ significantly, the 
data represented a new model (Snedecor \& Cochran, 1989).

From the $\tau_{\max }$ equation and considering the levels of normal stress, a multivariate model was adjusted for each treatment (Cerrado, and no-tillage and conventional tillage systems): $\tau_{\max }=10^{\left(\mathrm{a}+\mathrm{bU}+\mathrm{co} \sigma_{\mathrm{n}}\right)}$. This model allowed estimating maximum shear stress according to the normal stress applied and to the soil water content, which, in this case, were independent variables. The model, therefore, describes the ultimate soil shear strength as a function of certain soil water content, for a given level of normal stress.

The experimental setup was a randomized complete block design, with three replicates. The Sigma Plot software, version 4.0 (Jandel Corporation, San Rafael, USA) was used to make the graphs.

\section{Results and Discussion}

The highly significant Mohr-Coulomb parameters and the high coefficient of determination $\left(\mathrm{R}^{2}=0.99\right)$ observed for all equations indicate an excellent performance of the procedure used in the direct shear tests (Table 2). The apparent cohesion intercept (c) and the internal friction angle reduced with increasing water content in no-tillage and conventional tillage systems. The soil under Cerrado, however, did not follow the same pattern. Silva \& Carvalho (2007)

Table 2. Tunning parameters of the equations obtained from samples of Latossolo Vermelho distrófico (Rhodic Haplustox) under different uses and soil management systems, and soil water content based on the Mohr-Coulomb envelope $\left(\tau=\mathrm{c}+\sigma_{\mathrm{n}} \operatorname{tg} \phi\right)$.

\begin{tabular}{|c|c|c|c|c|}
\hline \multirow{2}{*}{$\begin{array}{l}\text { Soil water content } \\
\left(\mathrm{kg} \mathrm{kg}^{-1}\right)\end{array}$} & \multicolumn{4}{|c|}{ Parameters of the Mohr-Coulomb envelope ${ }^{(1)}$} \\
\hline & $\mathrm{c}$ & $\sigma_{\mathrm{n}}$ & $\phi$ & $\mathrm{R}^{2}$ \\
\hline & \multicolumn{4}{|c|}{ Cerrado } \\
\hline 0.05 & $119 * *$ & $0.97 * *$ & 44 & $0.99 * *$ \\
\hline 0.16 & $98 * *$ & $0.92 * *$ & 42 & $0.98 * *$ \\
\hline 0.27 & $131 * *$ & $0.70 * *$ & 35 & $0.97 * *$ \\
\hline \multirow[t]{2}{*}{0.38} & $103 * *$ & $0.61 * *$ & 31 & $0.99 * *$ \\
\hline & \multicolumn{4}{|c|}{ No-tillage } \\
\hline 0.05 & $148 *$ & $0.86 * *$ & 41 & $0.99 * *$ \\
\hline 0.16 & $106^{*}$ & $0.80 * *$ & 39 & $0.99 * *$ \\
\hline 0.27 & $58 *$ & $0.67 * *$ & 34 & $0.99 * *$ \\
\hline \multirow[t]{2}{*}{$\underline{0.38}$} & $28 *$ & $0.65 * *$ & 33 & $0.99 * *$ \\
\hline & \multicolumn{4}{|c|}{ Conventional tillage } \\
\hline 0.05 & $102 * *$ & $0.90 * *$ & 42 & $0.99 * *$ \\
\hline 0.16 & $87 * *$ & $0.87 * *$ & 41 & $0.99 * *$ \\
\hline 0.27 & $53 * *$ & $0.73 * *$ & 36 & $0.99 * *$ \\
\hline 0.38 & $46 * *$ & $0.71 * *$ & 35 & $0.99 * *$ \\
\hline
\end{tabular}

${ }^{(1)} \mathrm{c}$, apparent cohesion intercept; $\sigma_{\mathrm{n}}$, normal stress $(\mathrm{kPa})$; and $\phi, \tan ^{-1} \mathrm{~b}$. * and **Significant at 5 and $1 \%$ probability, respectively. found differences between apparent cohesion and internal friction angle, when assessed at the different soil water contents.

Maximum shear stress decreased exponentially with increasing soil water content, and reduction in normal stress shifted these curves downwards (Figure 1). These results agree with Khan \& Hoag (1978), which reported the effect of normal stress on the shear strength of the soil, during the rupture of cohesive soil samples subjected to different soil water contents. The range of normal stress $(97-1,551 \mathrm{kPa})$ and water contents $\left(0.05-0.38 \mathrm{~kg} \mathrm{~kg}^{-1}\right)$ evaluated in the present study comprehend highly adverse conditions of load applied to the soil. Silva et al. (2009) also observed that soil shear strength increased with the applied normal stress, resulting in greater contact between soil particles and greater internal friction angle. The authors stated that apparent cohesion intercepts and internal friction angles - and, consequently, Coulomb equations - vary between plant rows and traffic tracks.

Models differed from each other according to the normal stress applied and to their water content (Table 3). Silva et al. (2004) and Carvalho et al. (2010) verified that soil use and management can influence cohesion intercept, internal friction angle, and, therefore, shear stress. Larney \& Kladivko (1989) reported that shear stress increased in the surface of soils cultivated with moldboard plow. Munkholm et al. (2001) found that apparent cohesion in soils under the first crop was higher in reduced tillage, compared to conventional tillage. Schjonning \& Rasmussen (2000) observed lower shear stress in reduced tillage in evaluations right after planting; however, in the subsequent years, especially at deeper layers, reduced tillage increased soil shear strength, when compared to conventional tillage.

The models of maximum shear stress, adjusted for each soil use or management system (Table 4), were similar when the effect of normal stress was isolated $\left[\tau_{\max }=\mathrm{f}(\mathrm{U})\right]$. This result probably occurred because the models for Cerrado and no-tillage were similar, when subjected to $1,551 \mathrm{kPa}$ normal stress $-\mathrm{F}$ test revealed homogeneity, and linear and angular coefficients did not differ significantly. Therefore, data from both models were grouped, generating a new model for the behavior of the maximum shear stress in function of water content for the Cerrado and no-tillage treatments. 
No-tillage

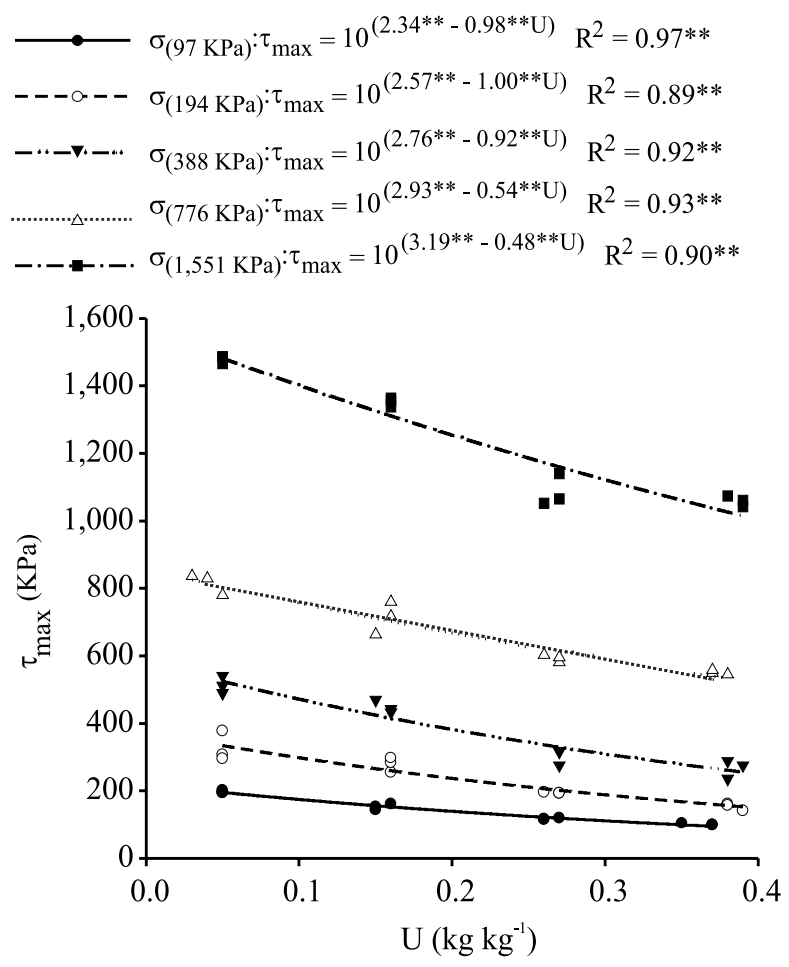

Conventional tillage

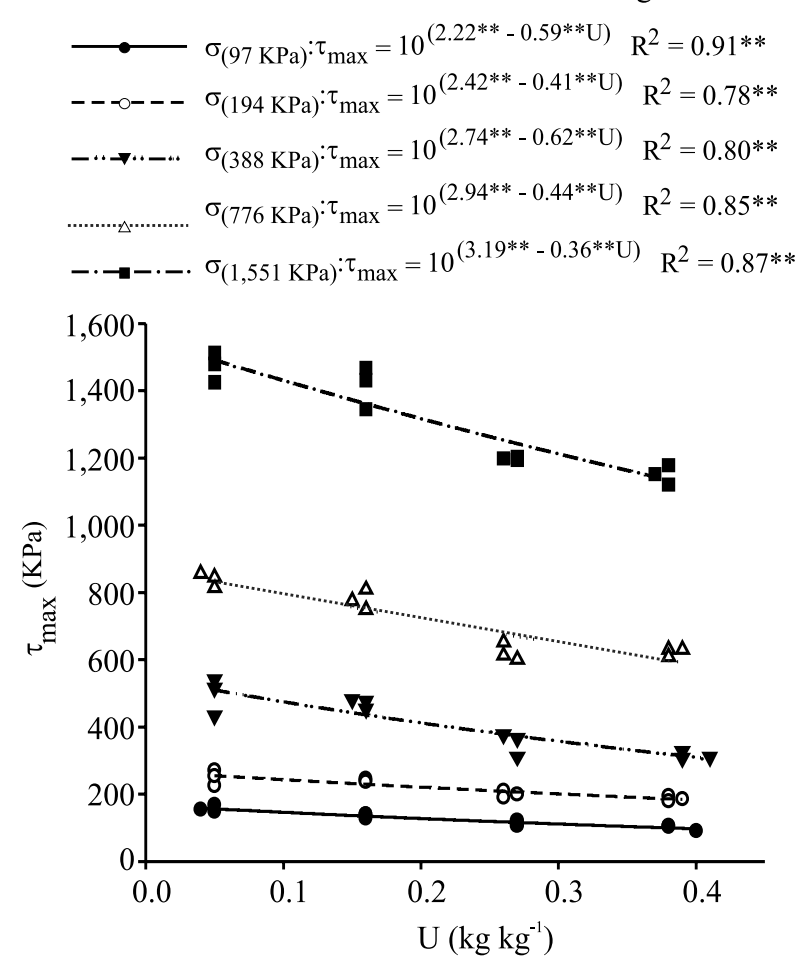

Cerrado

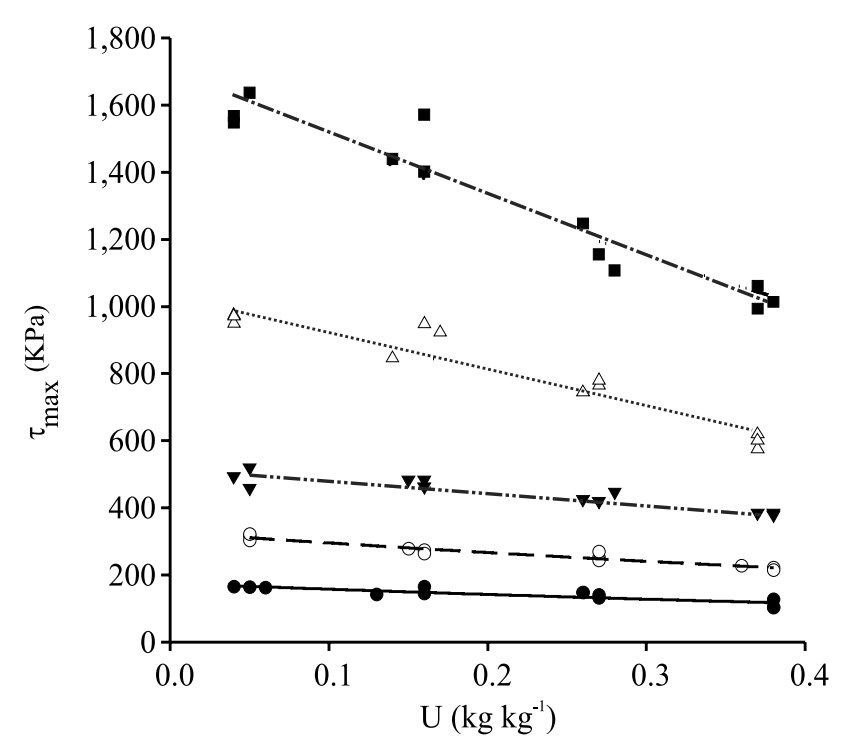

Figure 1. Maximum shear stress $\left(\tau_{\max }\right)$ of a Latossolo Vermelho distrófico (Rhodic Haplustox) under no-tillage, conventional tillage, and Cerrado, at $0.00-0.05 \mathrm{~m}$ depth, for each evaluated level of normal stress $\left(\sigma_{\mathrm{n}}\right)$, according to soil water contents (U). **Significant at $1 \%$ probability. 
The soil under Cerrado had higher maximum shear stress than the soil under conventional tillage, for all normal stresses evaluated, except $1,551 \mathrm{kPa}$, regardless of the water content (Figure 2). The same behavior was observed in the comparison involving the no-tillage system, but only in higher soil water contents. Ekwue \& Stone (1995) reported a similar model behavior.

The highest soil shear strength was registered in Cerrado soil, probably due to the high content of soil organic matter (Table 1). Soil organic matter

Table 3. Comparison between equations from the univariate model $\tau_{\max }=10^{(\mathrm{a}+\mathrm{bU})}$, after linearization of normal stresses $(\sigma)$ in the soil management systems, using the procedure proposed by Snedecor \& Cochran (1989).

\begin{tabular}{|c|c|c|c|}
\hline \multirow[t]{2}{*}{ Normal stress $(\mathrm{kPa})$} & \multirow[t]{2}{*}{ Equation } & \multicolumn{2}{|c|}{ Tunning parameters } \\
\hline & & Slope (b) & Linear coefficient (a) \\
\hline & \multicolumn{3}{|c|}{ Cerrado } \\
\hline$\sigma_{(97)}$ VS. $\sigma_{(194)}$ & $* *$ & ns & $* *$ \\
\hline$\sigma_{(97)}$ VS. $\sigma_{(388)}$ & $* *$ & ns & $* *$ \\
\hline$\sigma_{(97)}$ VS. $\sigma_{(776)}$ & ns & ns & $* *$ \\
\hline$\sigma_{(97)}$ VS. $\sigma_{(1,551)}$ & $*$ & ns & $* *$ \\
\hline$\sigma_{(194)}$ VS. $\sigma_{(388)}$ & ns & $*$ & $* *$ \\
\hline$\sigma_{(194)}$ VS. $\sigma_{(776)}$ & $*$ & $*$ & $* *$ \\
\hline$\sigma_{(194)}$ VS. $\sigma_{(1,551)}$ & ns & $*$ & $* *$ \\
\hline$\sigma_{(388)}$ VS. $\sigma_{(776)}$ & ns & $* *$ & $* *$ \\
\hline$\sigma_{(388)}$ VS. $\sigma_{(1,551)}$ & ns & $* *$ & $* *$ \\
\hline \multirow[t]{2}{*}{$\sigma_{(776)}$ Vs. $\sigma_{(1,551)}$} & ns & ns & $* *$ \\
\hline & \multicolumn{3}{|c|}{ Conventional tillage } \\
\hline$\sigma_{(97)}$ VS. $\sigma_{(194)}$ & ns & $*$ & $* *$ \\
\hline$\sigma_{(97)}$ VS. $\sigma_{(388)}$ & ns & ns & $* *$ \\
\hline$\sigma_{(97)}$ VS. $\sigma_{(776)}$ & ns & ns & $* *$ \\
\hline$\sigma_{(97)}$ VS. $\sigma_{(1,551)}$ & ns & $* *$ & $* *$ \\
\hline$\sigma_{(194)}$ VS. $\sigma_{(388)}$ & ns & ns & $* *$ \\
\hline$\sigma_{(194)}$ VS. $\sigma_{(776)}$ & ns & ns & $* *$ \\
\hline$\sigma_{(194)}$ VS. $\sigma_{(1,551)}$ & ns & ns & $* *$ \\
\hline$\sigma_{(388)}$ VS. $\sigma_{(776)}$ & ns & ns & $* *$ \\
\hline$\sigma_{(388)}$ Vs. $\sigma_{(1,551)}$ & $* *$ & * & $* *$ \\
\hline \multirow[t]{2}{*}{$\underline{\sigma}_{(776)}$ VS. $\sigma_{(1,551)}$} & ns & ns & $* *$ \\
\hline & \multicolumn{3}{|c|}{ No-tillage } \\
\hline$\sigma_{(97)}$ VS. $\sigma_{(194)}$ & $*$ & ns & $* *$ \\
\hline$\sigma_{(97)}$ VS. $\sigma_{(388)}$ & $*$ & ns & $* *$ \\
\hline$\sigma_{(97)}$ vs. $\sigma_{(776)}$ & $\mathrm{ns}$ & $* *$ & $* *$ \\
\hline$\sigma_{(97)}$ VS. $\sigma_{(1,551)}$ & ns & $* *$ & $* *$ \\
\hline$\sigma_{(194)}$ VS. $\sigma_{(388)}$ & ns & ns & $* *$ \\
\hline$\sigma_{(194)}$ VS. $\sigma_{(776)}$ & $*$ & $* *$ & $* *$ \\
\hline$\sigma_{(194)}$ VS. $\sigma_{(1,551)}$ & $*$ & $* *$ & $* *$ \\
\hline$\sigma_{(388)}$ VS. $\sigma_{(776)}$ & $*$ & $* *$ & $* *$ \\
\hline$\sigma_{(388)}$ VS. $\sigma_{(1,551)}$ & $*$ & $* *$ & $* *$ \\
\hline$\sigma_{(776)}$ VS. $\sigma_{(1,551)}$ & ns & ns & $* *$ \\
\hline
\end{tabular}

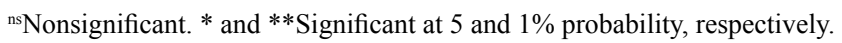

increases soil resistance to compression, reducing bulk density and increasing soil elasticity (Braida et al., 2010; Barbosa \& Lima, 2013). Tisdall \& Oades (1982) concluded that organic matter increases soil aggregation and, therefore, enhances its natural mechanical strength.

When comparing the soils under the conventional tillage and no-tillage systems, the former showed higher resistance, which may be associated with its management history, characterized by successive crop cycles, and can be confirmed by the higher values of soil density and saturated hydraulic conductivity (Table 1). These results are consistent with the ones obtained by Larney \& Kladivko (1989). The influence of traffic on soil shear strength is also in accordance with Servadio et al. (2001).

The area under the no-tillage system had lower values of maximum shear stress, despite the strength

Table 4. Comparison between equations from the univariate model $\tau_{\max }=10^{(\mathrm{a}+\mathrm{bU})}$, after linearization of the effects of soil management systems according to the evaluated normal stresses $\left(\sigma_{\mathrm{n}}\right)$, using the procedure proposed by Snedecor \& Cochran (1989).

\begin{tabular}{|c|c|c|c|}
\hline \multirow[t]{2}{*}{ Management } & \multirow[t]{2}{*}{ F test } & \multicolumn{2}{|c|}{ Tunning parameters } \\
\hline & & \multicolumn{2}{|c|}{ Slope (b) Linear coefficient (a) } \\
\hline & \multicolumn{3}{|c|}{$\sigma=97(\mathrm{kPa})$} \\
\hline Cerrado vs. conventional tillage & ns & ns & $* *$ \\
\hline Cerrado vs. no-tillage & * & $* *$ & ns \\
\hline \multirow[t]{2}{*}{ Conventional tillage vs. no-tillage } & ns & $* *$ & ** \\
\hline & \multicolumn{3}{|c|}{$\sigma=194(\mathrm{kPa})$} \\
\hline Cerrado vs. conventional tillage & * & ns & $* *$ \\
\hline Cerrado vs. no-tillage & * & $* *$ & $* *$ \\
\hline \multirow[t]{2}{*}{ Conventional tillage vs. no-tillage } & ns & $* *$ & ns \\
\hline & \multicolumn{3}{|c|}{$\sigma=388(\mathrm{kPa})$} \\
\hline Cerrado vs. conventional tillage & $* *$ & $* *$ & $* *$ \\
\hline Cerrado vs. no-tillage & $* *$ & ** & $* *$ \\
\hline \multirow[t]{2}{*}{ Conventional tillage vs. no-tillage } & ns & $*$ & $*$ \\
\hline & \multicolumn{3}{|c|}{$\sigma=776(\mathrm{kPa})$} \\
\hline Cerrado vs. conventional tillage & ns & $*$ & $* *$ \\
\hline Cerrado vs. no-tillage & ns & ns & $* *$ \\
\hline \multirow[t]{2}{*}{ Conventional tillage vs. no-tillage } & ns & ns & $* *$ \\
\hline & \multicolumn{3}{|c|}{$\sigma=1,551(\mathrm{kPa})$} \\
\hline Cerrado vs. conventional tillage & ns & $* *$ & ns \\
\hline Cerrado vs. no-tillage & ns & ns & ns \\
\hline \multirow[t]{2}{*}{ Conventional tillage vs. no-tillage } & ns & ns & $*$ \\
\hline & \multicolumn{3}{|c|}{$\begin{array}{l}\text { Recalculating } \mathrm{F} \text { for the managements } \\
\text { that did not wdiffer significantly }\end{array}$} \\
\hline $\begin{array}{l}\text { Cerrado + no-tillage vs. } \\
\text { conventional tillage }\end{array}$ & ns & $* *$ & ns \\
\hline
\end{tabular}



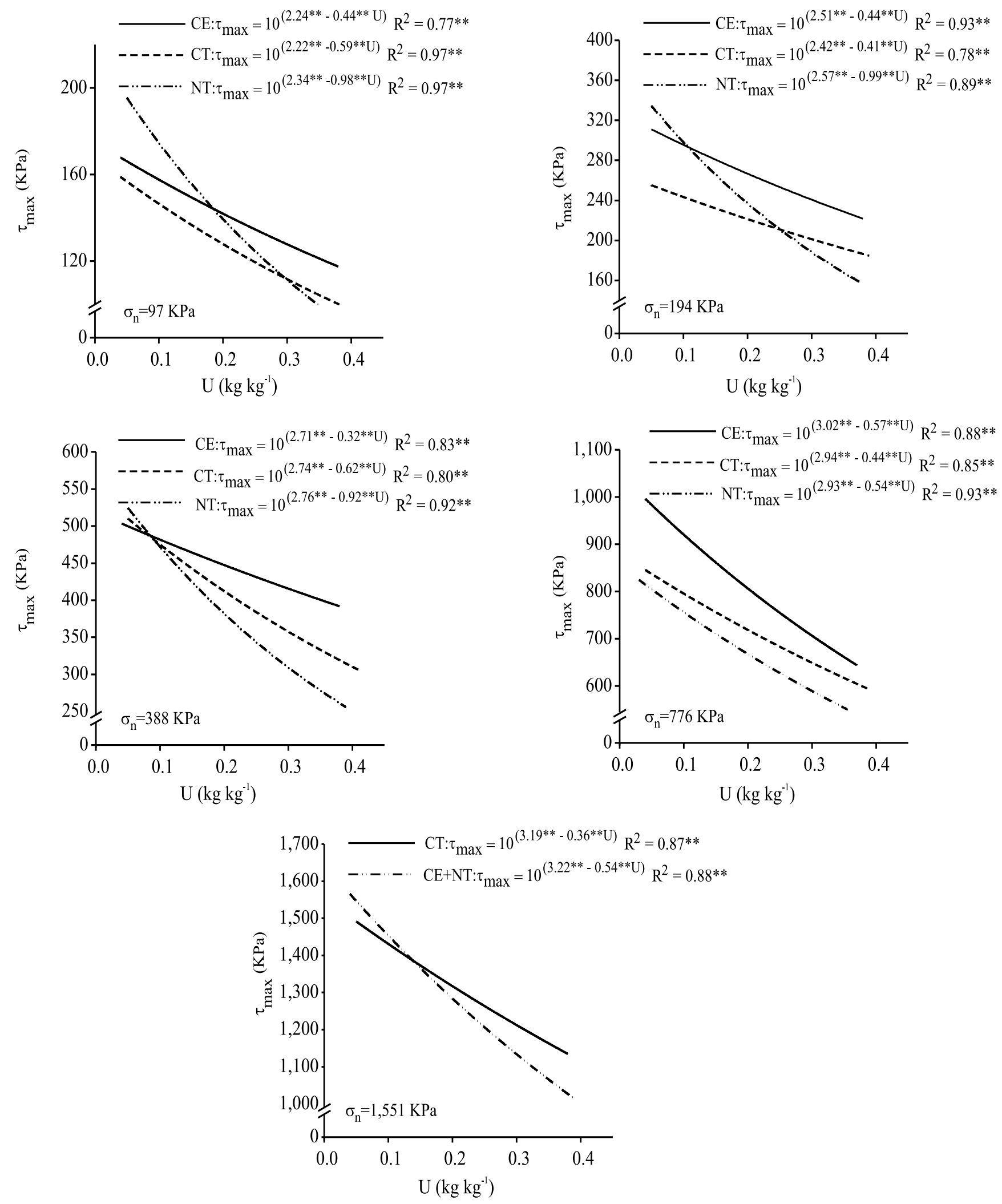

Figure 2. Maximum shear stress $\left(\tau_{\max }\right)$ of a Latossolo Vermelho distrófico (Rhodic Haplustox) under no-tillage $(\mathrm{NT})$, conventional tillage (CT), and Cerrado (CE), at 0.00-0.05 m depth, subjected to different soil water contents (U) and normal stresses $\left(\sigma_{\mathrm{n}}\right) \cdot{ }^{*}$ Significant at $1 \%$ probability. 
caused by the lack of tillage and the traffic associated with the machinery. Therefore, the normal stress at 97, 194, and $388 \mathrm{kPa}$ (Figure 2) would certainly represent a truer reality of contact pressures applied to agricultural soils in the Cerrado region. Furthermore, the normal stress of $388 \mathrm{kPa}$, between soil water contents of 0.20 and $0.30 \mathrm{~kg} \mathrm{~kg}^{-1}$ - within the friable range (Table 1) -, shows the higher shear strength of the soil under Cerrado, followed by the ones under the conventional tillage and no-tillage systems.

At the normal stress of $1,551 \mathrm{kPa}$, maximum soil shear strength did not differ significantly between Cerrado and no-tillage systems (Table 3). At this normal stress, between the soil water contents of 0.20 and $0.30 \mathrm{~kg} \mathrm{~kg}^{-1}$, higher soil shear strength was observed in the area under conventional tillage, followed by Cerrado and no-tillage. It is noteworthy to point out that, at this same stress level, shear response of the three managements, below the soil water content of $0.20 \mathrm{~kg} \mathrm{~kg}^{-1}$, was the same as that at $776 \mathrm{kPa}$. This reiterates the importance of evaluating soil shear strength, combining the effects of the factors water content and normal stress, whenever possible.

The correlation coefficient ranged from 0.92 to 0.95 , when the multivariate model, combining normal stress and water content $\left[\tau_{\max }=10^{\left(\mathrm{a}+\mathrm{bU}+\sigma_{\sigma_{n}}\right)}\right]$, was used (Figure 3). The maximum shear strength that can be applied to the soil before its rupture at the three soil consistency limits (shrinkage limit, plastic limit, and liquid limit) was assumed to be equivalent to the values of precompression stress at these limits (Table 1).

Conventional tillage provided the highest values of maximum soil shear strength, significantly higher than that of the other managements, in all consistency limits (Figure 4). The increased resistance observed with this management system was mainly due to the higher values of soil precompression stress, which resulted from lower water content at the consistency limits and from higher traffic intensity, as evidenced by the high values of soil density (Table 1). This same association was verified by Servadio et al. (2001), who reported a positive correlation between soil density and shear stress in a depth from 0.00 to $0.10 \mathrm{~m}$ in a path used by two different tractors.

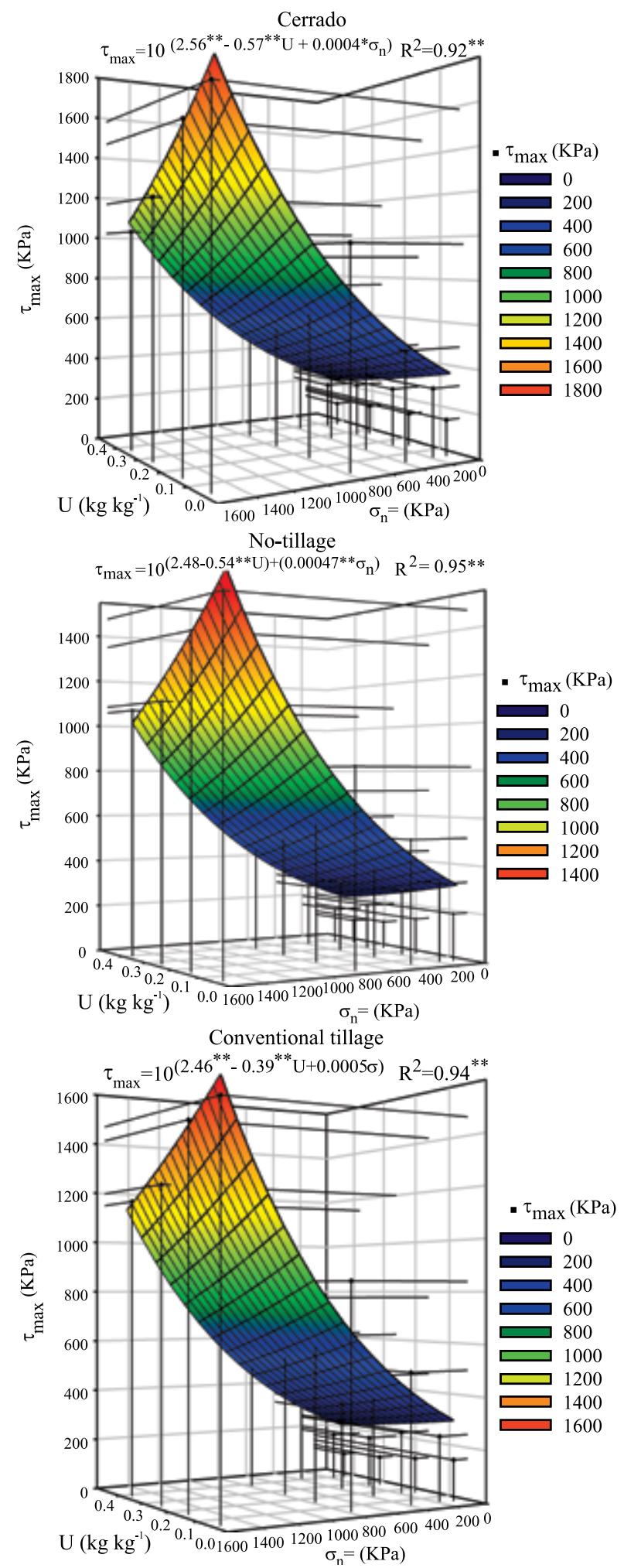

Figure 3. Maximum shear stress $\left(\tau_{\max }\right)$ of a Latossolo Vermelho distrófico (Rhodic Haplustox) under no-tillage, conventional tillage, and Cerrado, at 0.00-0.05 $\mathrm{m}$ depth, according to soil water contents $(\mathrm{U})$ and normal stresses $\left(\sigma_{\mathrm{n}}\right)$. $*$ and $* *$ Significant at 5 and $1 \%$ probability, respectively. 


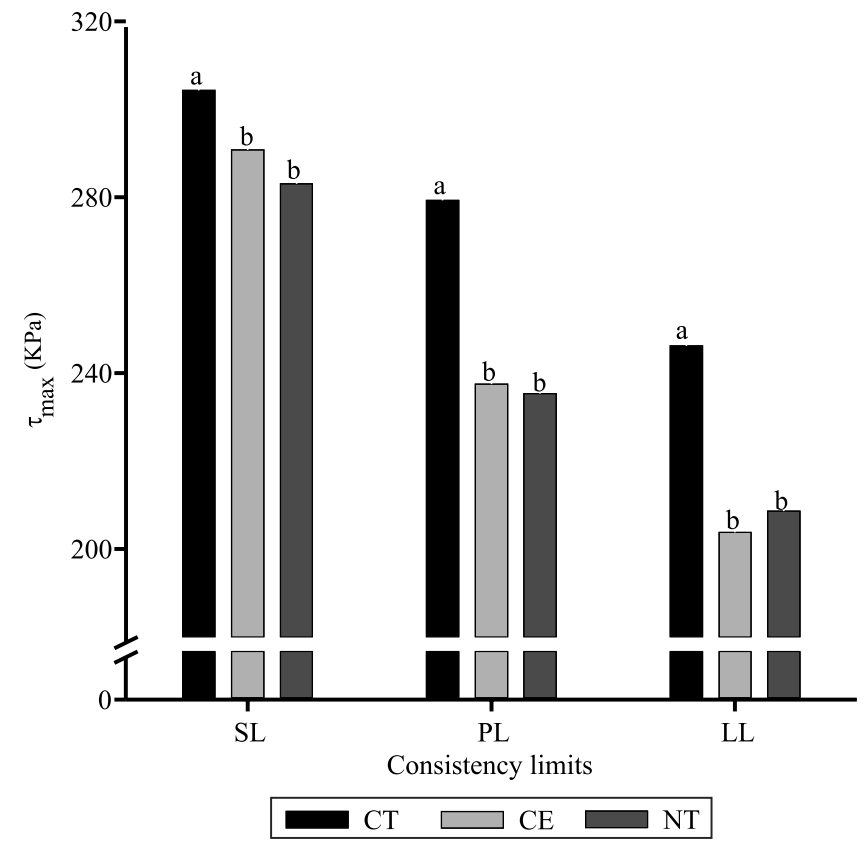

Figure 4. Maximum shear stress $\left(\tau_{\max }\right)$ of a Latossolo Vermelho distrófico (Rhodic Haplustox) estimated by the multivariate model $\tau_{\max }=10^{\left(\mathrm{a}+\mathrm{bU}+\mathrm{c} \sigma_{\mathrm{n}}\right)}$, according to soil consistency limits - SL, shrinkage limit; PL, plastic limit; and LL, liquid limit - and to the precompression stress, considered as normal stress, under no-tillage, conventional tillage, and Cerrado, at 0.00-0.05 $\mathrm{m}$ depth.

\section{Conclusions}

1. The models $\tau_{\max }=10^{(\mathrm{a}+\mathrm{bU})}$ and $\tau_{\max }=10^{\left(\mathrm{a}+\mathrm{bU}+\mathrm{c} \sigma_{\mathrm{n}}\right)}$, adjusted for the soils under the three management systems, satisfactorily explain the relationship between soil water content $(U)$, normal stress $\left(\sigma_{n}\right)$, and maximum shear stress of the soil $\left(\tau_{\max }\right)$.

2. The soil under Cerrado has the highest shear strength to normal stress values above $97 \mathrm{kPa}$, estimated by the univariate model, independently of soil water content.

3. The interaction between $U$ and $\sigma_{n}$, combined in a single equation, enhances the sensibility of the multivariate model in detecting soil management effects on soil shear strength, as was the case with the model $\tau_{\max }=10^{\left(2.46+0.39 \mathrm{U}+0.0005 \mathrm{c}_{\mathrm{n}}\right)}$, which revealed higher shear strength in conventional tillage.

\section{Acknowledgments}

To Conselho Nacional de Desenvolvimento Científico e Tecnológico (CNPq), for scholarship; to Embrapa Cerrados for granting access to the experimental area.

\section{References}

AJAYI, A.E.; DIAS JÚNIOR, M.S.; CURI, N.; OKUNOLA, A.; SOUZA, T.T.T.; PIRES, B.S. Assessment of vulnerability of Oxisols to compaction in the Cerrado Region of Brazil. Pedosphere, v.20, p.252-260, 2010. DOI: 10.1016/S1002-0160(10)60013-6.

ARAUJO, M.A.; TORMENA, C.A.; SILVA, A.P. Propriedades físicas de um Latossolo Vermelho distrófico cultivado e sob mata nativa. Revista Brasileira de Ciência do Solo, v.28, p.337-345, 2004. DOI: 10.1590/S0100-06832004000200012.

ARAUJO-JUNIOR, C.F.; DIAS JUNIOR, M. de S.; GUIMARÃES, P.T.G.; ALCÂNTARA, E.N. Capacidade de suporte de carga e umidade crítica de um Latossolo induzida por diferentes manejos. Revista Brasileira de Ciência do Solo, v.35, p.115-131, 2011. DOI: $10.1590 / \mathrm{S} 0100-06832011000100011$.

BACHMANN, J.; CONTRERAS, K.; HARTGE, K.H.; MACDONALD, R. Comparison of soil strength data obtained in situ with penetrometer and with vane shear test. Soil and Tillage Research, v.87, p.112-118, 2006. DOI: 10.1016/j.still.2005.03.001.

BARBOSA, J.A.; DIAS JUNIOR, M. de S.; VIEIRA, L.B.; DIAS, G.P. Resistência ao cisalhamento de um Argissolo Vermelho-Amarelo submetido ao tráfego de um trator agrícola. Revista Brasileira de Engenharia Agrícola e Ambiental, v.8, p.321-325, 2004. DOI: 10.1590/S1415-43662004000200024.

BARBOSA, M.C.R.; LIMA, H.M. de. Resistência ao cisalhamento de solos e taludes vegetados com capim vetiver. Revista Brasileira de Ciência do Solo, v.37, p.113-120, 2013. DOI: 10.1590/ S0100-06832013000100012.

BRAIDA, J.A.; REICHERT, J.M.; REINERT, D.J.; VEIGA, M. da. Teor de carbono orgânico e a susceptibilidade à compactação de um Nitossolo e um Argissolo. Revista Brasileira de Engenharia Agrícola e Ambiental, v.14, p.131-139, 2010. DOI: 10.1590/ S1415-43662010000200003.

CARVALHO, R. de C.R.; ROCHA, W.W.; PINTO, J.C.; PIRES, B. da S.; DIAS JUNIOR, M. de S.; NUNES, A.H.B. Soil shear strength under non-irrigated and irrigated short duration grazing systems. Revista Brasileira de Ciência do Solo, v.34, p.631-638, 2010. DOI: $10.1590 / \mathrm{S} 0100-06832010000300004$.

DONAGEMA, G.K.; CAMPOS, D.V.B. de; CALDERANO, S.B.; TEIXEIRA, W.G.; VIANA, J.H.M. (Org.). Manual de métodos de análise de solos. 2.ed. rev. Rio de Janeiro: Embrapa Solos, 2011. 230p. (Embrapa Solos. Documentos, 132).

EKWUE, E.I.; STONE, R.J. Organic matter effects on the strength properties of compacted agricultural soils. Transaction of the ASAE, v.38, p.357-365, 1995. DOI: 10.13031/2013.27804. 
HOSSAIN, M.A.; YIN, J.-H. Shear strength and dilative characteristics of an unsaturated compacted completely decomposed granite soil. Canadian Geotechnical Journal, v.47, p.1112-1126, 2010. DOI: 10.1139/T10-015.

IORI, P.; DIAS JUNIOR, M. de S.; AJAYI, A.E.; GUIMARÃES, P.T.G.; PAIS, P.S.M.; ANDRADE, M.L. de C. Comparison of field and laboratory models of the load bearing capacity in coffee plantations. Ciência e Agrotecnologia, v.37, p.130-137, 2013. DOI: $10.1590 / \mathrm{S} 1413-70542013000200003$.

IORI, P.; DIAS JÚNIOR, M. de S.; SILVA, R.B. da. Resistência do solo à penetração e ao cisalhamento em diversos usos do solo em áreas de preservação permanente. Bioscience Journal, v.28, p.185-195, 2012a.

IORI, P.; SILVA, R.B. da; DIAS JÚNIOR, M. de S.; LIMA, J.M. de. Pressão de preconsolidação como ferramenta de análise da sustentabilidade estrutural de classes de solos com diferentes usos. Revista Brasileira de Ciência do Solo, v.36, p.1448-1456, 2012b. DOI: $10.1590 / \mathrm{S} 0100-06832012000500008$.

KHAN, M.H.; HOAG, D.L. Three-dimensional stress-strain relationships of unsaturated soils. American Society of Agricultural Engineers, v.78, p.88-91, 1978.

LAMBE, T.W. Soil testing for engineers. New York: John Wiley $\&$ Sons, 1951. 165p.

LARNEY, F.J.; KLADIVKO, E.J. Soil strength properties under four tillage systems at three long-term study sites in Indiana. Soil Science Society of America Journal, v.53, p.1539-1545, 1989. DOI: $10.2136 /$ sssaj1989.03615995005300050041x.

MARASCA, I.; OLIVEIRA, C.A.A. de; GUIMARÃES, E.C.; CUNHA, J.P.A.R. da; ASSIS, R.L. de; PERIN, A.; MENEZES, L.A.S. Variabilidade espacial da resistência do solo à penetração e do teor de água em sistema de plantio direto na cultura da soja. Bioscience Journal, v.27, p.239-246, 2011.

MUNKHOLM, L.J.; SCHJONNING, P.; RASMUSSEN, K.J. Non-inversion tillage effects on soil mechanical properties of a humid sandy loam. Soil and Tillage Research, v.62, p.1-14, 2001. DOI: 10.1016/S0167-1987(01)00205-7.

PAIS, P.S.M.; DIAS JUNIOR, M. de S.; SANTOS, G.A. dos; DIAS, A.C.; GUIMARÃES, P.T.G.; ALCÂNTARA, E.N. de. Compactação causada pelo manejo de plantas invasoras em Latossolo Vermelho-Amarelo cultivado com cafeeiros. Revista Brasileira de Ciência do Solo, v.35, p.1949-1957, 2011. DOI: 10.1590/S0100-06832011000600011.

PIRES, B.S.; DIAS JUNIOR, M. de S.; ROCHA, W.W.; ARAUJO JUNIOR, C.F.; CARVALHO, R. de C.R. Modelos de capacidade de suporte de carga de um Latossolo Vermelho-Amarelo sob diferentes usos e manejos. Revista Brasileira de Ciência do Solo, v.36, p.635-642, 2012. DOI: 10.1590/S0100-06832012000200032.

SANTOS, H.G. dos; JACOMINE, P.K.T.; ANJOS, L.H.C. dos; OLIVEIRA, V.A. de; OLIVEIRA, J.B. de; COELHO, M.R.; LUMBRERAS, J.F.; CUNHA, T.J.F. (Ed.). Sistema brasileiro de classificação de solos. 2.ed. Rio de Janeiro: Embrapa Solos, 2006. $306 \mathrm{p}$.

SCHJONNING, P.; RASMUSSEN, K.J. Soil strength and soil pore characteristics for direct drilled and ploughed soils. Soil and Tillage Research, v.57, p.69-82, 2000. DOI: 10.1016/ S0167-1987(00)00149-5.

SERVADIO, P.; MARSILI, A.; PAGLIA, M.; PELLEGRINE, S.; VIGNOZZI, N. Effects on some clay qualities following the passage of rubber-tracked and wheeled tractors in central Italy. Soil and Tillage Research, v.61, p.143-155, 2001. DOI: 10.1016/ S0167-1987(01)00195-7.

SEVERIANO, E. da C.; OLIVEIRA, G.C. de; DIAS JÚNIOR, M. de S.; CASTRO, M.B. de; OLIVEIRA, L.F.C. de; COSTA, K.A. de P. Compactação de solos cultivados com cana-de-açúcar: I. Modelagem e quantificação da compactação adicional após as operações de colheita. Engenharia Agrícola, v.30, p.404-413, 2010. DOI: $10.1590 / \mathrm{S} 0100-69162010000300005$.

SILVA, A.J.N. da; CARVALHO, F.G. de. Coesão e resistência ao cisalhamento relacionadas a atributos físicos e químicos de um Latossolo Amarelo de tabuleiro costeiro. Revista Brasileira de Ciência do Solo, v.31, p.853-862, 2007. DOI: 10.1590/ S0100-06832007000500003.

SILVA, R.B.; DIAS JUNIOR, M.S.; SANTOS, F.L.; FRANZ, C.A.B. Resistência ao cisalhamento de um Latossolo sob diferentes uso e manejo. Revista Brasileira de Ciência do Solo, v.28, p.165-173, 2004. DOI: 10.1590/S0100-06832004000100016.

SILVA, R.B.; IORI, P.; SILVA, F.A.M.; LANÇAS, K.P.; DIAS JÚNIOR, M.S. Modelagem e determinação do estado crítico de consolidação a partir da relação massa e volume em solos canavieiros. Revista de Ciências Agrárias, v.33, p.376-389, 2010.

SILVA, R.B.; LANÇAS, K.P.; MIRANDA, E.E.V.; SILVA, F.A.M.; BAIO, F.H.R. Estimation and evaluation of dynamic properties as indicators of changes on soil structure in sugarcane fields of Sao Paulo State Brazil. Soil and Tillage Research, v.103, p.265-270, 2009. DOI: 10.1016/j.still.2008.10.018.

SNEDECOR, G.W.; COCHRAN, W.G. Statistical methods. Ames: Iowa State University Press, 1989. 503p.

TISDALL, J.M.; OADES, J.M. Organic matter and water-stable aggregates in soils. Journal of Soil Science, v.33, p.141-163, 1982. DOI: 10.1111/j.1365-2389.1982.tb01755.x. 